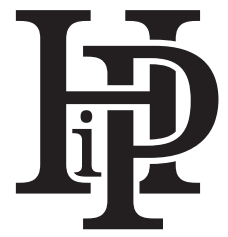

Historia i Polityka

No. 30(37)/2019, pp. 89-106

www.hip.umk.pl (c) (1) $\Theta$

ISSN 1899-5160, e-ISSN 2391-7652

DOI: http://dx.doi.org/10.12775/HiP.2019.038

Paweł PASZAK

War Studies University, Faculty of National Security, Warszawa, Poland

\title{
Sino-Russian Partnership in the Face of Changing Balance of Power and Internal Barriers
}

\author{
Chińsko-rosyjskie partnerstwo w obliczu zmieniającej się równowagi sił \\ i wewnętrznych barier
}

\section{- Abstrakt •}

Celem niniejszego artykułu jest opis i krytyczna ocena głównych kwestii spornych w stosunkach chińsko-rosyjskich oraz wyjaśnienie, w jaki sposób wpływają one na rozwój tej relacji. W pierwszej kolejności w artykule badane są stanowiska Chin i Rosji względem ich partnerstwa w kontekście zmieniającej się dystrybucji potęgi i zjawiska narastającej rywalizacji w Azji Centralnej. Następnie analizowany jest wpływ kolektywnie rozumianego Zachodu na dynamikę chińsko-rosyjskiego partnerstwa, ze szczególnym uwzględnieniem roli Stanów Zjednoczonych. Wnioski te zostają uzupełnione o ocenę regionalnej percepcji relacji w regionie Azji i Pacyfiku oraz studium wymiany handlowej pomiędzy dwiema stronami. Autor nie ogranicza się do jednego podejścia metodologicznego, czerpiąc $\mathrm{z}$ teorii równoważenia zagrożenia, koncepcji dylematu bezpieczeństwa oraz dokonując analizy dyskursu politycznego i struktury wymiany handlowej. Rezultaty analizy wskazują na istnienie relatywnie stałych i istotnych barier, sugerujących, że relacje chińsko-rosyjskie nie osiągną wyższego poziomu intensywności, niż to jest w chwili obecnej. Obecna forma współpracy umożliwia

\section{- Abstract •}

The aim of this article is to describe and critically assess the main contentious issues in Sino-Russian relations and to explain how they affect the development of this relationship. First of all, the article examines the attitudes of China and Russia towards their relationship in the context of the changing distribution of power and increasing competition in Central Asia. Secondly, the influence of the collectively understood West on the dynamics of the Sino-Russian partnership is analyzed, with particular emphasis on the role of the United States. These applications are supplemented with an assessment of regional perception of relations in the Asia-Pacific region and a study of trade between two parties. The author does not limit himself to one methodological approach, drawing from the Balance of Threat Theory, the concept of security dilemma and analyzing political discourse and structure of bilateral trade. The results of the analysis indicate the existence of relatively permanent and significant barriers, suggesting that the Sino-Russian relations will not reach a higher level of intensity than is the case at present. The current form of cooperation enables both parties to pursue com- 
obydwu stronom realizację wspólnych interesów bez nadmiernego ryzyka asertywnej reakcji ze strony Stanów Zjednoczonych. Tylko gwałtowne i daleko idące zmiany, szkodliwe dla obu państw, mają szansę doprowadzić do takiego sprzężenia interesów Chin i Rosji, by zawiązały one w pełni operacyjny sojusz.

Słowa kluczowe: Chiny; Rosja; partnerstwo; sojusz; rywalizacja mon interests without risking an assertive reaction from the United States. Only sudden and far-reaching changes, harmful to both countries, have a chance to bring about a convergence of China's and Russia's interests sufficient to create a fully operational alliance.

Keywords: China; Russia; partnership; alliance; rivalry

\section{Introduction}

Post-2008 period has witnessed a dynamic development of Sino-Russian strategic partnership encompassing political, military and economic dimensions. Beijing and Kremlin have finalised several strategic projects, such as $\$ 250$ billion crude oil supply agreement in 2013, $\$ 400$ billion gas deal in 2014, as well as contracts for Russian SU-35 aircrafts and S-300 SAM systems scheduled to be delivered in 2018. The two countries have also regularly participated in several joint military exercises such as Peace Operation under the auspices of SCO (Shanghai Cooperation Organization), Vostock-2018, naval drills in the South-China Sea and even manoeuvers in the Mediterranean. Moscow and Beijing have also successfully prevented any substantial progress on the UN Security Council in regards to Syrian Civil War and worked closely to maintain stability in Central Asia. In 2010 China became Russia's top trading partner, and bilateral trade in 2018 is expected to reach $\$ 100$ billion - a considerable shift when compared with a modest $\$ 7,5$ billion in 2000 (The World Bank, 2018). Amid Western sanctions imposed on Russia following the annexation of Crimea and the ongoing trade war between the US and China, Vladimir Putin and Xi Jinping have even further intensified contacts on intergovernmental level. Chinese and Russian leaders have endorsed a partially shared vision of multipolar world countering "hegemonic" order imposed by the United States (Bolt, 2014, pp. 49-50; Ambrosio, 2017, pp. 127-133; Chebankova, 2017). All these developments sparked a lively debate among scholars and experts about the real substance of the relationship and potential implications for the US and the international security environment (Kaczmarski, 2016; Korolev, 2018; Korolev \& Portyakov, 2018; Malle, 2017; Charap, Drennan, \& Noël, 2017; Wishnick, 2017). Some prominent Chinese experts like Yan Xuetong have even advocated Sino-Russian alliance as the best solution to the perceived US threat (Ruonan \& Feng, 2017). In the face of shifting gravity of power towards Asia and 
the crisis of liberal order (Ikenberry, 2018) the Sino-Russian partnership has to be regarded as one of the most significant determinants of stability in the Asia-Pacific region. An accurate assessment of driving forces and major constraints will help to comprehensively understand the ongoing dynamics of the relationship and predict its potential development.

The article aims to describe and critically assess major impediments of People's Republic of China and the Russian Federation. The author attempts to resolve whether analyzed constraints prove sufficient to prevent Sino-Russian strategic partnership from evolving into an alliance. The hypothesis assumes that while Sino-Russian rapprochement is a fact, there are also apparent internal and external limitations determining how far China and Russia can move their relationship forward. Despite shared interests in the political spectrum, there are too many vested interests and constraints for an alliance to emerge. In contrast to other works in the field, the article addresses the problem comprehensively embracing political, ideational and economic dimensions. The author does not limit himself to one methodological approach, drawing from the Balance of Threat Theory, the concept of security dilemma and analyzing political discourse and structure of bilateral trade.

In the first section, the article explores China's and Russia's attitudes towards their relationship in the context of changing distribution of power and arising competition in Central Asia. The second section focuses on the influence Western states exert on the Sino-Russian strategic partnership. The particular focus is given to the role of the United States in shaping China-Russia relations and Washington's potential reaction to the development of a formal alliance between Moscow and Beijing. The third section attempts to explain how the regional perception of the relationship in the Asia-Pacific affects strategic choices of China and Russia. In the last section, the author analyses the scope and structure of bilateral trade, investigating how it is perceived in Beijing and Moscow and to what extent it can meet the expectations of both parties.

\section{Bold Rhetoric and Ambiguity: Russia's and China's Approaches to the Partnership}

On May $9^{\text {th }}$, 2015, during Russia's $70^{\text {th }}$-anniversary celebrations of the Victory Day President Putin declared that Russian-Chinese relations are "on the rise and undergoing the best period in their centuries-long history" (Hille, 2016). These words have been almost literally repeated by the Chinese Foreign Minister and 
State Councilor Wang Yi during his trip to Moscow in April 2018 who expressed his belief that "China-Russia relations are in the best period of history" (Tiezzi, 2018). Are these far-reaching declarations just friendly rhetoric or do they announce the establishment of a new strategic alliance in Asia? How this positive narrative fares up in a confrontation with interests, strategies and constraints of both countries?

On the one hand, the relationship is unquestionably at the highest level since the conclusion of the Cold War and collapse of the USSR as exemplified by deepening political, military and economic cooperation. However, is it enough to assume that the partnership is evolving towards an alliance? Russia's and China's officials have on many occasions claimed that they are not interested in allying. Recently it has been expressed in China's 2015 White Paper on Defense. The document assures that "China's armed forces will continue to develop military-to-military relations that are non-aligned, non-confrontational and are not directed against any third party" (The State Council Information Office of the People's Republic of China, 2015). This position is consistent with the traditional approach of Beijing which since the early 1980s endorsed the policy of independent foreign policy and non-alignment with any bloc or states. Beijing has developed a tendency to perceive alliances as a "zero-sum" game aimed at containment of other countries (Liff, 2018, pp. 140-141).

One may conclude that strategic goals can also be achieved through an informal alliance, so China and Russia do not need an official agreement to pursue their common agenda and contest Western supremacy. However, a closer analysis of mutual perception and underlying interests provides strong arguments to dismiss this view. Despite the cordial rhetoric, some circles of Russian political elites are becoming increasingly concerned about changing dynamics in the relationship between their once dominant country and China, and advocate a "balancing strategy" as the most reasonable solution (Huasheng, 2013). Since the conclusion of the Cold War Russia's approach towards China was based on pragmatic presumptions, nevertheless political circles have been divided over the issue (Kuchins, 2010, pp. 38-41). Most of the elites envisaged Russia's future intertwined with Europe and the United States, giving much less attention to China. This approach has evolved in the face of shifting gravity of power in favor of China and the downfall of Russia's relationship with the West. Presently, the most popular view expressed by the government circles and members of the ruling party - United Russia - assumes China's constructive role in world politics and Russia's development (Solomentseva, 2014, pp. 5-10). The positive narrative has been employed more vigorously after the Ukrainian crisis when China emerged as the only viable 
strategic option for Moscow. Vladimir Putin and other prominent government figures have debunked the "alarmist" attitude to China's rise numerous times claiming that there is no real threat to the Russian Far East and no competition between Moscow and Beijing in Central Asia (Solomentseva, 2014, pp. 5-10). But does this narrative hold up in confrontation with the facts? Russia and China have a long tradition of rivalry stretching back to Cold War and manifested in public opinion surveys. On the one hand, Russians hold a positive view of China (around $64 \%$ in 2014) but, on the other, most of them interprets China's military rise as a threat to Russia (around 74\% in 2011; Solomentseva, 2014, pp. 29-30). The official discourse, predominantly controlled by the Kremlin authorities, has avoided directly naming China as a potential threat. However, the implicit suspicions persist especially in regards to the Russian Far East and Central Asia (Saradzhyan, 2010). In the case of China and Russia official rhetoric should not be taken for granted, given that Beijing expresses "friendliness" and cooperative attitudes also toward India or the US despite unquestionable rivalry. Russia and China may effectively cooperate in some areas such as energy, military or international politics, but it does not mean that two sides cannot become competitors in other spheres. The rapprochement also does not rule out implicit security considerations, which cannot be expressed due to the persisting rules of political secrecy regarding sensitive issues of national security.

Zhao Huasheng argues that the ambiguous attitude of Russian intellectual elites towards China has been a common feature of China-Russia relations preventing them from advancing to a higher level (Huasheng, 2013). Rising disproportions concerning economic power to the detriment of Russia and the relative dwindling of Russia's political and military advantage over China calls into question the very foundations of their relationship. China's economy is already over 7.7 times larger ( $\$ 12,23$ tn vs $\$ 1,57$ tn; Trading Economics, 2019) than Russia's, its military budget over 3,5 times larger ( $\$ 228$ bn vs $\$ 66$ bn; SIPRI, 2019) and according to available estimates, these disparities will continue to grow.

Russian circles involved in foreign-policy making are afraid of being marginalized in Central Asia, and in Asian politics in general. Given that Russia's identity pursues confirmation of its great power status and restoration of once preeminent position, it will be difficult for Russian elites to accept being downgraded to a second-class partner. Nothing more precisely illustrates these underlying tensions as the development of the SCO, which since its establishment in 2001 has become an arena of competition between Russia and China. The SCO's initial mission was to tackle the so-called "three evils" - religious extremism, ethnic separatism, and international terrorism (Yuan, 2010), nevertheless, quickly after the establishment, 
Beijing pushed for the broadening of the organization's agenda. Kremlin, being aware of Chinese advantages in the field of economy, advocated cooperation centered around security issues while China strived to advance economic cooperation (Kaczmarski, 2017; Haas, 2017, pp. 10-12). Russians perceive Central Asia as its traditional sphere of influences, view cemented by cultural affinity, historical links from the USSR period (Ackerman, 2003) as well as geopolitical considerations (Umland, 2009). Newly independent republics which emerged after the dissolution of the Soviet Union are perceived in Russian political circles as "near abroad" - the term which highlights Russia's claim to the privileged position in this region. The inception of SCO has created a framework which is not entirely dominated by Russia and provides Central Asian states with new policy options. The Chinese initiative has broken Kremlin's monopoly in security, political and economic dimensions. Struggling Russian economy, over-dependent on the export of fuels, has been unable to effectively compete with vigorous Chinese counterparts offering technical expertise and investment capital. For that reason, Russia so far has obstructed any developments within the SCO framework that would lead to the evolution towards strengthened economic cooperation and give China the upper hand. In 2010, Russia thwarted Beijing's initiative to create an SCO development bank and a free-trade zone between members of the organization. Instead, Russia convinced China to join Eurasian Development Bank co-owned by Russia and Kazakhstan. In subsequent years, Moscow lobbied for incorporation of India into the organization - country which recognizes China as a major threat and rival (Panda, 2013) - in order to balance China's rising influence. The idea came to fruition in 2017 when India was finally admitted to SCO, yet the success was only partial as China effectively lobbied for Pakistan to be included as well. Islamabad's involvement in the process neutralized leverage gained by Russia, as Pakistan remains India's enemy and proven partner of China. Despite Moscow's efforts to maintain control over the organization, some commentators predict that in the coming future China will become "the primary leader" of SCO. China, facing opposition from Russia within the organization, has pursued deepening its ties with the region autonomously as part of the Belt and Road Initiative (BRI) and on a bilateral basis. The New Silk Road aims to bind Central Asia politically and economically to China through wide-ranging investments in the infrastructure alongside outlined economic corridors (Yu, 2017). As of 2015, China pledged to provide at least $\$ 150$ billion in order to support infrastructure project, most of which will be funded by the newly established Asian Investment and Infrastructure Bank (AIIB) jointly with other Chinese banks, private investors and local governments. 
Realistically, Putin's administration is unable to present a counterproposition for a project of this grandeur, so instead of impeding its progress, he has to accept a lesser role and engage with Chinese counterparts. After 2014 and shift towards Asia, Putin had to reconcile with the idea of China's greater influence in its "near border". Nevertheless, putting up with undesired circumstances should not be taken for enthusiasm towards Chinese projects, which gradually move post-soviet republics away from Russia's exclusive orbit of influence. Having this in mind, the establishment of Eurasian Economic Union in 2014 by Russia seems to be aimed at preserving Russian influences challenged by the allure of the China's New Silk Road (Kaczmarski, 2017). Russia's imperial identity in conjunction with national interests might likely produce more dissenting voices as China will expand its foothold, undermining the willingness to cooperate with China. Central Asian countries since the end of the Cold War have been both economically and politically dependent on Kremlin. Rapprochement with the European Union, NATO or the US was not a viable option, due to geographical remoteness, Moscow's established influences and divergent approaches towards democracy. Examples of Georgia, Moldova and finally Ukraine help to better understand the scale of a challenge for any country of the former USSR to get out from Russia's sphere of influence. China's rise to power and engagement with the region has opened new possibilities for Central Asian countries to loosen their ties with Kremlin. Farkhod Tolipov underscores that Russia's revisionist and neo-imperial behavior towards Georgia, Moldova and Ukraine did not only result in condemnation and sanctions from the West but also aroused fears among Central Asian states (Tolipov, 2015, pp. 11-21). Tolipov further concludes that Kremlin's hardline approach has made region's leaders think about the stability of their power, even though these suspicions have not been expressed explicitly (Tolipov, 2015, p. 11). Kremlin's political circles are aware of unfavorable dynamics in the region, for a long time considered to be Russia's exclusive orbit of influence. Detrimental changes in the political environment may result in actions aimed at halting China's advances, giving rise to tension in mutual relations. In this context, it is worth noting that PRC and USSR in the 1950s have been bound by a formal military alliance, before competition for power, influence and ideological primacy within the socialist bloc almost led to regular conflict between two countries. Clashes on Amur River in 1969 have soured relations for the coming decades, pushing China in 1972 to align with the United States. Circumstances are different now, and it would be delusional to claim that history will repeat itself, yet historical experiences, lingering suspicions and vested interests endure which might negatively affect the Sino-Russian relationship. 


\section{China, Russia and the West}

Russia's and China's relation with the West, and with the United States in particular, can be identified as one of the key factors determining the dynamics of Sino-Russian partnership. In the case of Russia at least since the Enlightenment, the West has been a primary reference point for the construction of national identity (Szostek, 2017; Tsygankov, 2007), vital strategic interests and economy. In many cases relations with China acted as a function of Kremlins current relationship with the West. Historically, the same mechanism can be distinguished in China's shift towards the United States in 1972 in order to minimize the risk of war with the USSR. Recently pattern can be observed in Russia's realignment with the US after the 9/11 terrorist attack on World Trade Centre towers in 2001. At that moment Putin calculated that the tactic of bandwagoning with financially preponderant America is the key to the restoration of Russian economy (Wilson, 2005, p. 165). Russia has made its Central Asian bases accessible to Americans launching a campaign in Afghanistan, in next year it accepted American withdrawal from the ABM treaty, signed SORT agreement and took a bitter pill by accepting the accession of Baltic States to NATO. Having on the horizon the return to the "table" with the US, relations with anti-hegemonic Beijing has been relegated to the secondary status. The policy pursued by Putin has quickly proved to be ineffective as the Bush administration did not appreciate Russia's concessions. A reorientation towards confrontation and closer cooperation with Beijing since 2003 was a natural consequence of Moscow's disappointment with the US. In 2007 Putin gave a strong anti-American speech at Munich Security Conference signaling a definite return to more confrontational approach towards the West.

The process of Sino-Russia rapprochement gained a new impetus in the aftermath of the 2008 global financial crisis bringing dire implication upon Russian economy. Russia's "eastern pivot" has started from 2008-2009 and resulted from rising awareness that overdependence on Western markets is a double-edged sword that alongside multiple benefits can potentially drag its economy down. Russian elites also assimilated the idea that closer engagement with the Asia-Pacific region in the fields of security and economy is essential to maintain Russia's great-power status (Korolev, 2016, pp. 55-59). War in Georgia, the annexation of Crimea in 2014 and Western sanctions that followed have deepened Russia's diplomatic isolations and exacerbated state of its structurally flawed economy. These developments have stimulated China-Russia relations, mainly because of Russia's deteriorating international position and the pursuit of great-power status confirmation. Since then, Russian diplomacy worked intensively to improve bilateral 
trade and investment relations with China in order to compensate for political and financial loses. It is not a coincidence that it was in 2014 when China and Russia had concluded a $\$ 400$ billion gas deal after ten years of stalling talks. In this particular moment, internal and external factors converged to enable a breakthrough in negotiations. However, due to Russia's weak negotiating position, agreed prices were significantly lower than prices paid by European states, showing that political rationale prevailed over economic considerations.

Regarding enhancing Sino-Russian cooperation, another profound step was taken with the signing of the $\$ 3$ billion contracts for the delivery of six S-400 surface-to-air missile systems, scheduled to arrive in China by 2018. These developments exemplify to what extent China's and Russia's international behavior is driven by the actual state of their relations with the West. Whenever Russia's relations with the West improve, the relation with China weakens, whenever Moscow faces opposition from the United States or the European Union, it pursues closer cooperation with Beijing. Currently, Russia's diplomatic fallout with the West and China's trade war with the US facilitate rapprochement, but is this convergence sufficient to create conditions for an alliance to emerge? International pressures brought Moscow and Beijing closer, but are they enough to compel them to ally?

The Balance of Threat Theory developed by Stephen Walt assumes that the formation of alliances and coalitions is determined not purely by sheer power, but rather by the perception of threats to national security (Walt, 1990; Walt, 1985). Walt contends that states will generally balance not by allying against the most powerful state, as the Balance of Power Theory argued it (Waltz, 1979, pp. 118-121), but by allying against a state which is deemed as the most pressing threat. Donald Trump by imposing tariffs on imports from China, upholding sanctions on Russia and withdrawing from the INF nuclear treaty has proven that he will counterbalance perceived threats to America's strategic interests in Asia. This approach has found a clear manifestation in America's National Defense Strategy naming China and Russia "revisionist" powers and identifying them as major components of new longterm strategic competition (USA Department of Defense, 2018). The trade war with China, INF pullout and new Defense Strategy illustrate a typical deterrence strategy defined as the use of threats to dissuade other actors from taking a particular action. Basing on current strategic assumptions and experiences of the Cold War containment strategy, most likely a Sino-Russian alliance would be treated by the US as an offensive action, detrimental to the US security. That, in turn, would incite some containment policy involving the use of economic means as well as forming a regional coalition involving Japan, South Korea, Taiwan, Australia, India and other willing states. These developments would almost certainly reduce China's chances 
of becoming a global superpower and a developed economy. The scenario is an undesirable option both for Russia and China, mostly because most of their interest, especially in China's case, concentrate in the US and its allies.

Authorities in Beijing are aware of these risk which is reflected in diplomatic documents and statements made by most prominent officials. In 2014, at CICA conference (Conference on Interaction and Confidence Building Measures in Asia) president Xi Jinping criticised the Asian "Cold War security structure [in which] some big powers pursue security as a 'zero-sum game' and keep strengthening military alliances in the region while excluding the common interests of other countries" (Liff, 2018, p. 137). In April 2018, President Xi stated that "In today's world, the trend of peace and cooperation is moving forward and a Cold War mentality and zero-sum game thinking are outdated" (BBC, 2018). In a similar tone Wang Yi, PRC's foreign minister, in September 2018 called to abandon "Cold War Mentality" (Top Chinese Diplomat, 2018). These statements are particularly intriguing when taken into consideration that realist perspective (assuming a zero-sum game as one of critical features of international relations) is the one that dominates in China's strategic thinking (Xu \& Du, 2015; Liff, 2018, p. 233; Lubina, 2017, p. 15). Chinese foreign policy circles by no means perceive its competition with the US as a "win-win" but rather in terms of losing or winning the race for global hegemony (Mingfu, 2015).

Similarly to Chinese counterparts, Russian officials have voiced their disapproval of new US military strategy - President Vladimir Putin's spokesman, Dmitry Peskov, accused it of "imperial character" and told the press that Russia "cannot accept that the country is treated as a threat to the security of the United States" (Radio Free Europe, 2017). The high risk of confrontation with the US provides a very strong if not the single most important argument for Chinese and Russian governments to refrain from forming an alliance. The United States administration maintaining a significant advantage in terms of military and economic power can still successfully balance China's and Russia's development. American reaction to China challenge fits into classical security dilemma situation when a decision-maker has to decide which behaviors of other actors are defensive or offensive in nature and how to respond to protect its vital interests. The strategic culture of the United States which involves elements of Monroe doctrine, Alfred Mahan's naval expansionism, experiences of George Kennan's containment policy with the conjunction with Donald Trump hardline approach suggest that the reaction of the United States will be far reaching and assertive. The wide range of tools the American administration still has at its disposal constitutes a powerful deterrent to the creation of Sino-Russian alliance. 


\section{Regional Perception of Sino-Russian Partnership - the Risk of Security Dilemma and Counterbalancing}

Both Russia and China have to take into consideration not only the US reaction but also growing regional concerns over the remarkable rise of China's power as well as Beijing's intransigent approach to securing its perceived interests in Asia-Pacific region. The broad scope of cooperation manifested in joint military exercises, diplomatic support and arms deal can potentially impede Putin's efforts towards finding new partners in East and South-East Asia. Countries like India, Vietnam or Indonesia are recipients or potential destinations for Russian arms export, vital for lifting the troubled economy. On the other hand, Japan and South Korea are economic powerhouses that can substantially accelerate the development of the Russian Far East and help invigorate stagnant economy through investments. For Indian government, China is regarded as one of the most substantial threats, as both countries compete for position and power both on the global stage as well as in South and South-East Asia (Frankel, 2011). Furthermore, Beijing's "all-weather partnership" with India's archrivals Pakistan and the New Maritime Silk Road deepens the feeling of mistrust and strategic encirclement among political elites in New Delhi (Singh, 2008; Holslag, 2009). Yet, Russia has a long tradition of cooperation with India stretching back to the Cold War period - the tradition which is also continued today despite Sino-Indian rivalry and the India-US rapprochement. Two contracts for the purchase of S-400 systems and four Talwar-class frigates worth respectively $\$ 2,2$ billion and $\$ 5,5$ billion highlight the importance of India as a partner for Russia, position that Moscow does not intend to spoil by excessive movements towards Beijing or Islamabad. India remains a key partner in Asia, being a useful counterweight to China's rising influences, for that reason Moscow successfully advocated for India's inclusion to SCO. The same logic applies to Vietnam and Indonesia, both important destinations of Russian arms exports and potential counterweights to China in the region.

However, it is not only Russian government that pays attention to the way neighbors perceive its actions. Xi Jinping alongside with his administration is deeply aware of possible consequences of classical security dilemma situation. China ascension to power would not have taken place if it had not been for a favorable international environment in the 2000s and 2010s, described by Chinese foreign policy experts as "window of strategic opportunity" (Medeiros, 2009, p. 17). China threat theory, growing concerns among Asian nations as well as balancing by the US create powerful obstacles for the restoration of China's once preeminent position in world politics. Chinese Communist Party is aware of this potential 
threat, and for that reason, in the past years much effort has been made in order to convince international society that China's rise is "peaceful" (Glaser \& Medeiros, 2007), China is still a "developing country" (Qin, 2014, p. 310) and all their policies are oriented towards "win-win cooperation" (Xi, 2017). These narratives have not been effectively embraced by international society as growing assertiveness in regards to territorial claims to Diaoyu/Senkaku Islands, South-China Sea dispute, Syrian civil war or recent diplomatic fallout with South Korea over the deployment of THAAD system put into question its veracity. Discrepancies between official rhetoric and political practice as well as a factual abandonment of the "low profile" policy introduced by Deng Xiaoping undermine the credibility of Beijing. Therefore PRC's authorities have to take their steps carefully to avoid unnecessary tensions with neighbors. Failure to comply with these requirements can trigger mechanism described by the Balance of Threat Theory and impede China's efforts to become a superpower on equal footing with the United States.

\section{Trade Cooperation - Asymmetrical, Unbalanced, Insufficient}

Since the beginning of the new millennium, the value of bilateral trade flows between the Russian Federation and China has grown significantly, prompting further discussion about the possible new alliance between two great powers. In 2000 , trade in goods amounted to modest $\$ 8$ billion, however in 2008 , it rose up to $\$ 56,82$ billion (The World Bank). The upward trend was temporarily interrupted in 2009 when the turnover of bilateral trade fell by a third to $\$ 38,78$ billion (The World Bank). This sudden change came in the aftermath of the global financial crisis which caused the sudden slump in prices of crude oil, worldwide decline in demand as well as asset withdrawal by investors. The 2010-2014 period was characterized by the further growth of bilateral trade reaching all-time high - \$95,19 billion in 2014. In 2015 and 2016, the trade value declined and totaled respectively to: $\$ 67,95$ billion and $\$ 70,56$ billion (The World Bank). Initially, Western sanctions have brought negative consequences upon Russia, yet it has only briefly affected Sino-Russian trade relations. In 2017, according to the Chinese Ministry of Commerce, bilateral trade rose up again to over $\$ 80$ billion, and in 2018 is expected to reach $\$ 100$ billion (China Russia Trade Volume..., 2018). Despite trade development, estimates show that Russia's share in Chinese export remain modest $(1,78 \%$ in 2016$)$ compared to other economic powers as the United States (18,39\%), Japan (6,16\%), South Korea (4,47\%), Germany (3,11\%), India (2,78\%), or the United Kingdom (2,65\%; The World Bank). Moreover, the 
structure of trade is highly unbalanced with China exporting high-value-added goods and Russia's exporting raw materials and fossil fuels. In 2017, out of $\$ 41,4$ billion of Russian exports to China mineral fuels and oils accounted for $\$ 27,43$ billion (66,2\%; International Trade Center, 2019).

Figures mentioned above highlight the fact that the Russian market is not capable of satisfying China's export demands to the degree Western markets can. Chinese authorities seeking to maintain high growth rates in the export-oriented economy have no choice but to maintain economic interdependence with the West and strive to increase domestic consumption. From the Russian perspective, exporting raw materials and low-value-added commodities is neither a satisfactory situation as it does not contribute significantly to the economy's development. While resource-based exports constitute a significant source of income for the Russian budget, they also lead to the deterioration of commodity sophistication. Instead of increasing the production of knowledge-intensive goods Russian economy still relies on raw material, minerals and fossil fuels risking remaining in the middle-income trap.

As it has been argued in the previous sections, forming an alliance with a high level of probability would be perceived by the US and its allies as aggressive behavior and balanced through political, economic and military means. The escalation of a trade war would substantially exacerbate China's development opportunities and implementation of impending social and economic strategies. The future success of ambitious goals such as Made in China 2025, China Dream, the Belt and Road Initiative, or Two Centenary Goals to a large degree relies on the stability of exports to developed markets and technological transfers from advanced economies. CCP's (China Communist Party) legitimacy is grounded not in the communist ideology, which has been long rejected by Chinese society as a result of the Cultural Revolution and Tiananmen massacre, but in economic success. Deterioration of living conditions and growth rates can prove dangerous to the stability of the Party, therefore maintaining positive economic dynamics stands as a priority for Chinese authorities. Reaching development goals set by the Party cannot be achieved without the Western openness to Chinese goods and services. The Donald Trump administration by the imposition of tariffs on imports from China signaled that it will balance any substantial Chinese gains that undermine the superior position of the United States. In this situation, the formation of an alliance between China and Russia seems like an unlikely possibility. 


\section{Conclusions}

The article aimed to present and analyze the influence of problematic issues in Sino-Russian relations on the further development of cooperation and formation of an alliance. It has been argued that growing concerns among part of Russian foreign policy circles about rising disproportions in their relations with China might potentially restrain the development of a closer partnership. Dissenting voices in Russia are grounded not only in the shifting distribution of power but also in China's expanding influences in Central Asia via the Belt and Road Initiative and Shanghai Cooperation Organization. Russia and China pursue different visions of regional cooperation in Central Asia according to their respective strengths, and in many dimensions, these strategic plans are not compatible. China wants to exert influence through economic means, while Russia prefers to concentrate on security and military cooperation simultaneously offsetting Beijing's economic advances through the Eurasian Economic Union. Lacks of cultural affinity between societies and elites as well as the insufficient political will to advance the relationship constitute an impediment for the relationship.

The risk of American reaction creates another powerful obstacle for the inception of an alliance. Donald Trump's administration through trade war with China and the pullout from the INF treaty has proved that it does not refrain from the use of coercive means to protect its strategic interest. As a sole superpower with global reach, it still holds a decisive advantage over Russia and China - a situation which is not projected to change over the next decades. The formation of the Sino-Russian alliance would undoubtedly provoke American reaction aiming at further containment of Russia and China according to the Balance of Threat Theory. Regional perception also comes into play, since Asian states such as India, Japan, Indonesia or Vietnam watchfully follow China's rising capabilities and willingness to project power in the Asia-Pacific.

Sino-Russian bilateral trade, despite high growth rates, still plays a secondary role in China's economic policy perceiving its strategic interests in developed Western economies. Sino-Western economic interdependence minimizes the chances of forming an alliance with Russia, as it would lead to a possible escalation of the ongoing trade war. The picture that emerges demonstrates that there are many relatively fixed impediments which suggest that Sino-Russian relationship is not likely to develop much further than it is now. The current framework of cooperation enables two sides to pursue their common interests without risking an assertive reaction from the external actors. Only a groundbreaking change in the international environment detrimental to both countries might create a convergence necessary to form an alliance. 


\section{References:}

Ackerman, E. (2003). Central Asia in the Mind of Russia: Some Political Considerations. Review of International Affairs, 2(4), 19-31. DOI: https://doi.org/10.1080/147535503 12331287542.

Ambrosio, T. (2017). The Architecture of Alignment: The Russia-China Relationship and International Agreements. Europe-Asia Studies, 69(1), 110-156. DOI: https://10. 1080/09668136.2016.1273318.

BBC (2018). US-China Trade: Xi Warns Against “Cold War Mentality”. April 10. Retrieved from: https://www.bbc.com/news/business-43708119.

Bolt, P.J. (2014). Sino-Russian Relations in a Changing World Order. Strategic Studies Quarterly, 8(4), 48-70.

Charap, S., Drennan, J., \& Noël, P. (2017). Russia and China: A New Model of Great-Power Relations. Survival. Global Politics \& Strategy, 59(1), 25-42. DOI: https://doi.org/10. 1080/00396338.2017.1282670.

Chebankova, E.E. (2017). Russia's Idea of the Multipolar World Order: Origins and Main Dimensions. Post-Soviet Affairs, 33(3), 217-234. DOI: https://doi.org/10.1080/ 1060586X.2017.1293394.

China-Russia Trade Volume Expected to Reach 100 bln USD this Year (2018). Xinhua. April 27. Retrieved from: http:/www.xinhuanet.com/english/2018-04/27/c_137141892.htm.

de Haas, M. (2017). Relations of Central Asia with the Shanghai Cooperation Organization and the Collective Security Treaty Organization. The Journal of Slavic Military Studies, 30(1), 1-16. DOI: https://doi.org/10.1080/13518046.2017.1271642.

Frankel, F.R. (2011). The Breakout of China-India Strategic Rivalry in Asia and the Indian Ocean. Journal of International Affairs, 64(2), 1-17.

Glaser, B.S, \& Medeiros, E.S. (2007). The Changing Ecology of Foreign Policy-Making in China: The Ascension and Demise of the Theory of "Peaceful Rise". The China Quarterly, 190, 291-310. DOI: https://doi.org/10.1017/S0305741007001208.

Hille, K. (2016). Russia and China: Friends with Benefits. Financial Times, February 5. Retrieved from: https://www.ft.com/content/f8959924-cab6-11e5-a8ef-ea66e967dd44.

Holslag, J. (2009). The Persistent Military Security Dilemma between China and India. Journal of Strategic Studies, 32(6), 811-840. DOI: https://doi.org/10.1080/01402390 903189592.

Huasheng, Z. (2013). Does China's Rise Pose a Threat to Russia? China Institute of International Studies. April 26. Retrieved from: http://www.ciis.org.cn/english/2013-04/26/ content_5908664.htm.

Ikenberry G.J. (2018). The End of Liberal International Order? International Affairs, 94(1), 7-23. DOI: https://doi.org/10.1093/ia/iix241.

International Trade Center (2019). International Trade Statistics 2001-2019. Retrieved from: http://www.intracen.org/itc/market-info-tools/trade-statistics/.

Kaczmarski, M. (2016). The Asymmetric Partnership? Russia’s Turn to China. International Politics, 53(3), 415-434. DOI: https://doi.org/10.1057/ip.2016.7. 
Kaczmarski, M. (2017). Two Ways of Influence-building: The Eurasian Economic Union and the One Belt, One Road Initiative. Europe-Asia Studies, 69(7), 1027-1046. DOI: https://doi.org/10.1080/09668136.2017.1373270.

Korolev, A. (2016). Russia's Reorientation to Asia: Causes and Strategic Implications. Pacific Affairs, 89(1), 53-73.

Korolev, A. (2018). On the Verge of an Alliance: Contemporary China-Russia Military Cooperation. Asian Security, 1-20. DOI: https://doi.org/10.1080/14799855.2018.1463991.

Korolev, A., \& Portyakov, V. (2018). China-Russia Relations in Times of Crisis: A Neoclassical Realist Explanation. Asian Perspective, 42(3), 411-437.

Kuchins, A. (2010). Russian Perspectives on China: Strategic Ambivalence. In: J. Bellacqua (ed.). The Future of China-Russia Relations (pp. 33-55). Lexington: The University Press of Kentucky.

Liff, A.P. (2018). China and the US Alliance System. The China Quarterly, 233, 137-165. DOI: https://doi.org/10.1017/S0305741017000601.

Lubina, M. (2017). Russia and China: A Political Marriage of Convenience - Stable and Successful. Opladen, Berlin, Toronto: Barbara Budrich Publishers.

Malle, S. (2017). Russia and China in the $21^{\text {st }}$ Century. Moving Towards Cooperative Behaviour. Journal of Eurasian Studies, 8(2), 136-150. DOI: https://doi.org/10.1016/j. euras.2017.02.003.

Medeiros, E.S. (2009). China's International Behavior. Activism, Opportunism and Diversification. RAND Project Airforce. Retrieved from: https://www.rand.org/content/ dam/rand/pubs/monographs/2009/RAND_MG850.pdf.

Mingfu, L. (2015). The China Dream: Great Power Thinking and Strategic Posture in the Post-American Era. New York: CN Times Books.

Panda, J.P. (2013). Competing Realities in China-India Multilateral Discourse: Asia's Enduring Power Rivalry. Journal of Contemporary China, 22(82), 669-690. DOI: https://doi.org/10.1080/10670564.2013.766386.

Ploberger, Ch. (2017). One Belt, One Road - China's new grand strategy. Journal of Chinese Economic and Business Studies, 15(3), 289-305. DOI: http://dx.doi.org/10.1080/1 4765284.2017.1346922.

Qin, Y. (2014). Continuity through Change: Background Knowledge and China's International Strategy. The Chinese Journal of International Politics, 7(3), 285-314. DOI: https://doi.org/10.1093/cjip/pou034.

Radio Free Europe (2017). Russia Calls U.S. Security Strategy "Imperial”, China Denounces "Cold War" Thinking. Radio Free Europe. Retrieved from: https://www.rferl.org/a/ trump-security-strategy-russia-china-reactions-cold-war-mentality/28926630.html.

Ruonan, L., \& Feng, L. (2017). Contending Ideas on China's Non-Alliance Strategy. The Chinese Journal of International Politics, 10(2), 151-171. DOI: https://doi.org/ 10.1093/cjip/pox003.

Saradzhyan, S. (2010). The Role of China in Russia's Military Thinking. Retrieved from: https://www.belfercenter.org/publication/role-china-russias-military-thinking.

Singh, S. (2008). India-China Relations: Perceptions, Problems, Potential. South Asian Survey, 15(1), 83-98. DOI: https://doi.org/10.1177/097152310801500106. 
SIPRI Military Expenditure Database (2019). Retrieved from: https://www.sipri.org/databases/milex.

Solomentseva, A. (2014). The "Rise" of China in the Eyes of Russia: A Source of Threats or New Opportunities? Connections, 14(1), 3-40. DOI: 10.11610/Connections.14.1.01.

Szostek, J. (2017). Defence and Promotion of Desired State Identity in Russia's Strategic Narrative. Geopolitics, 22(3), 571-593. DOI: https://doi.org/10.1080/14650045.2016. 1214910.

The State Council Information Office of the People's Republic of China (2015). China's Military Strategy. Retrieved from: http://eng.mod.gov.cn/Database/WhitePapers/.

The World Bank. (2018). Retrieved from: https://wits.worldbank.org/.

Tiezzi, S. (2018). China, Russia 'Show Americans' Their Close Relationship. The Diplomat. April 10. Retrieved from: https://thediplomat.com/2018/04/china-russia-show-americans-their-close-relationship/.

Tolipov, F. (2015). Strategic Implications of the War in Ukraine for the Post-Soviet Space: A View from Central Asia. Connections, 14(4), 11-21.

Trading Economics (2019). Retrieved from: https://tradingeconomics.com/china/gdp.

Tsygankov, A.P. (2007). Finding a Civilisational Idea: "West", "Eurasia," and "Euro-East” in Russia’s Foreign Policy. Geopolitics, 12(3), 375-399. DOI: https://doi. org/10.1080/14650040701305617.

Umland, A. (2009). Pathological Tendencies in Russian "Neo-Eurasianism": The Significance of the Rise of Aleksandr Dugin for the Interpretation of Public Life in Contemporary Russia. Russian Politics \& Law, 47(1), 76-89. DOI: https://doi.org/10.2753/ RUP1061-1940470104.

USA Department of Defense (2018). Summary of the 2018 National Defense Strategy of the United States of America: Sharpening the American Military's Competitive Edge. Retrieved from: https://dod.defense.gov/Portals/1/Documents/pubs/2018-National-Defense-Strategy-Summary.pdf.

Walt, S.M. (1985). Alliance Formation and the Balance of World Power. International Security, 9(4), 3-43.

Walt, S.M. (1990). The Origins of Alliances. Ithaca: Cornell University Press.

Waltz, K. (1979). Theory of International Politics. Mass: Addison-Wesley.

Wilson, J.L. (2005). Strategic Partners. Russian-Chinese relations in the Post-Soviet Era. London: Routledge.

Wishnick, E. (2017). In Search of the 'Other' in Asia: Russia-China Relations Revisited. The Pacific Review, 30(1), 114-132. DOI: https://doi.org/10.1080/09512748.2016.12 01129.

Xi, J. (2017). Work Together to Build the Silk Road Economic Belt and the 21 $1^{\text {st }}$ Century Maritime Silk Road (Speech at the Opening Ceremony of the Belt and Road Forum for International Cooperation, 14 May 2017).

Xu, J., \& Du, Z. (2015). The Dominant Thinking Sets in Chinese Foreign Policy Research: A Criticism. The Chinese Journal of International Politics, 8(3), 251-279. DOI: https://doi.org/10.1093/cjip/pov002. 
Yu, H. (2017). Motivation Behind China's "One Belt, One Road” Initiatives and Establishment of the Asian Infrastructure Investment Bank. Journal of Contemporary China, 26(105), 353-368. DOI: http://dx.doi.org/10.1080/10670564.2016.1245894.

Yuan, J.D. (2010). China's Role in Establishing and Building the Shanghai Cooperation Organization (SCO). Journal of Contemporary China, 19(67), 855-869. DOI: https:// doi.org/10.1080/10670564.2010.508587. 